\title{
Gender Differential Effect of Business Education Students' Human Capital on Sustainable Economic Development
}

\author{
James E. Edokpolor \\ Benson Idahosa University
}

\begin{abstract}
This research investigates the relationship between business education students' human capital and core values of sustainable economic development from a gender perspective. This research specifically investigates four interrelated questions. First, do male and female business education students experience different types of general human capital? Second, do male and female business education students possess different types of specific human capital? Third, do differences in both male and female business education students' general human capital have a differential effect on sustainable development of Nigerian economy? And finally, do differences in both male and female business education students' specific human capital have a differential effect on sustainable development of Nigerian economy? To answer these questions, bivariate correlation was employed. The hypotheses were tested using analysis of variance and multiple regressions. Using a survey data of all the final-year undergraduate students $(N=375)$ of business education in Federal Universities in SouthSouth geopolitical region of Nigeria, the results showed a positive correlation between general and specific human capital and core values sustainable development. Male and female business education students experience almost the same type of general human capital. The results also showed that male students possess higher level of specific human capital than female students. The results further showed that changes or variations in core values of sustainable development caused by both general and specific human capital are higher in male than the female students. Logical conclusions and implications for future practices are discussed.
\end{abstract}

Keywords: business education students, gender differential effect, human capital, sustainable economic development

\section{Introduction}

In September 2015, like every other Member States of the United Nations, Nigeria adopted the U.N. 2030 Agenda for Sustainable Development, which includes 17 goals, 169 targets, and 230 indicators. Specifically, Goals 4 and 5 of the Agenda stressed the need to ensure inclusive and equitable quality education and promote lifelong learning opportunities for all and achieve gender equality and empower all women and girls. The Federal Republic of Nigeria (FRN, 2017) in its Sustainable Development Goals (SDGs) stated that Goal 4 of the agenda shall be achieved via the "...acquisition of foundational and higher-order skills; greater and more equitable access to technical and vocational education and training and higher education; training throughout life; and the knowledge, skills and values needed to function well and contribute to society" (p. 4). It also pointed out that Goal 5 of the agenda

aims to empower women and girls to reach their full potential, which requires eliminating all forms of discrimination and violence against them, including harmful practices, violence by intimate partners, sexual violence and harmful practices, such as child marriage and female genital mutilation. (p. 4) 
The FRN further stipulated that Goal 5 of the agenda seeks to ensure that women have better access to paid employment, sexual, and reproductive health and reproductive rights; receive due recognition for their unpaid work; have real decision-making power in public and private spheres; have full access to productive resources; and enjoy equal participation with men in political, economic and public life.

The eighth World Environmental Education Congress (2015) in its summary report also offered a wide spectrum of the

possibilities for education and learning for a transition away from, what some speakers' referred to as, global systemic dysfunction and towards a healthier, more equitable and balance way of living. Not by propaganda, force or prescription but rather by discovering, (re)connecting, questioning, disrupting, experimenting, reflecting and, indeed, continuous learning. (p. 3)

This quotation and all other goals mentioned above inform the need for this extant research, aiming to examine the relationship between business education students' human capital and sustainable development of Nigerian economy from a gendered perspective.

Sustainability is understood in the wider sense as meeting individuals own needs without compromising abilities of future generations to meet their own needs (United Nations Educational Scientific and Cultural Organization, 2005; World Commission on Environment and Development, 1987; World Environmental Education Congress, 2015). Development in its economic sense refers to a certain process of improving the quality of human lives by raising their levels of living, self-esteem, and freedom (Todaro \& Smith, 2011). Bringing together these two set of concepts describes sustainable development as a continuous and progressive increase and expansion of a given economy with the improvement in the social, economic, and political life of the present and future generations (Kurya \& Hassan, 2007). This may be the reason why Hardi (1997) contended that sustainable development is not a fixed state of harmony; rather, it is an ongoing process of evolution in which individuals take actions leading to the development that meets their current needs without compromising the abilities of future generations to meet their own needs. Based on these conceptual clarifications, sustainable development of Nigerian economy is seen as persistent increase in economic growth, leading to economic competiveness, higher standard of living, and self-reliance (Ekpenyong \& Edokpolor, 2015). Sen (1999) reminded us that no individual is free if he or she cannot choose or is imprisoned by living on the margins of subsistence with no education and skill. Therefore, the fulfillment of the SDGs required active participation of the present and future generations; hence, skills development education and training (such as a business education program) are inevitable.

Business education is perhaps one of the major areas of vocational education in Nigeria that is critical to the development of higher-order thinking skills needed by the youths to function effectively in their entrepreneurial and educational careers right after graduation. Titiloye \& Muhammed (2016) indicated that business education is a program that prepares the mind, the brain, and the physical body of individuals toward positive contribution to development of societies. Thus, business education can be described as a major engine for improving core values of development. However, in our attempt to teach business education courses in the classroom, we have become aware of gender differences among students in their interests to participate in real-life learning tasks required to become entrepreneurs and lifelong learners upon graduation.

The word gender usually refers to as a social construct that establishes and differentiates status and role between men and women particularly in the way they contribute to, participate in and are rewarded by the economy as well as most social institutions (Ametefe \& Ametefe, 2007). Although women constitute a high percentage of students in business education across the globe (Miller \& 
Sisk, 2012), these same women seem not to have the interests to participate in real-life learning tasks in business education. It is disheartening that in spite of women's population in business education, their interest to participate in real-life learning is quite unimpressive. Early research found that interest factor is more influential as students grow older (Sammons, 1995). In fact, Carter and Silva (2010) found that women continue to lag men at every single career stage, right from their first professional careers. Some studies also explained the low position of women in career pursuits mainly by means of differences in human capital accumulation, arguing that women who are as well educated as men secure more or less the same earnings or status in their careers (Siphambe \& Thokweng-Bakwena 2001; Nordman \& Wolff, 2009; Kuépié, 2016). Goher (2013) rightly argued that educated married couples are often found to be helping hands for each other on different issues and prove to be lifelong learning sources for each other. Becker (1991) has indicated that women's important role in reproduction reduces their professional career productivity and human capital investment. As such, gender differences among business education students is not just an issue that is attributed to Nigeria alone, but globally, where only few percentage of top managers, entrepreneurs, rectors, provosts and vice-chancellors are women (Morley, 2013). Of course, one way to promote gender neutrality in business education is to have female professors who will be persuading female students verbally or given them positive encouragement and feedback, which is currently a major challenge, because business education tends to be dominated by male professors.

Based on the gender disparity, it therefore means that female business education students would lack feminine role models and executive guest speakers. This gender gaps among business education students have been recognized by the FRN (2017) and may be the reason why it stressed the need for vocational education sector (of which business education is a major part) to do more in closing the gender gap, stipulating that the SDG

focuses on the acquisition of foundational and higher-order skills; greater and more equitable access to technical and vocational education and training and higher education; training throughout life; and the knowledge, skills and values needed to function well and contribute to society. (p. 4)

In order for this goal to become a reality, technical and vocational education and training and higher education needs to tackle the "invisible barriers" that prevent women from progressing into entrepreneurial and lifelong learning activities. This speaks more on gender differences of business education students' human capital, which resulted in females being constantly judged as less having opportunity to contribute to sustainable development agenda. Although, an emerging research stream has focused on gender issues in business education (Ball, 2012; Blau, Mittal, Schirmer, \& Ozkan, 2017; Igbinedion \& Ojeaga, 2013; Kaenzig, Hyatt, \& Anderson, 2007; Kelan \& Jones, 2010; Riley, 1987; Simpson, 2006;). Despite the bulk of the research literature, the author of this study found no published research that specifically investigated gendered differential effect of business education students' human capital on sustainable development of Nigerian economy.

Human capital theory (Becker, 1964, 1975, 1993) and social feminist theory (Carter \& Williams, 2003; Fischer, Reuber, \& Dyke, 1993; Johnsen \& McMahon, 2005) were adopted as theoretical frameworks for this study. Because there is a pool of evidence of a correlation between human capital and sustainable development of the Nigerian economy (e.g., Adelakun, 2011; Ali, Egbetokun, \& Memon, 2017; Eigbiremolen \& Anaduaka, 2014; Ekperiware, Olatayo, \& Egbetokun, 2017; Idenyi, Eze, \& Ogbonna, 2016; Mba, Mba, Ogbuabor, \& Ikpegbu, 2013; Ogujiuba, 2013; Ogunleye, Owolabi, Sanyaolu, \& Lawal, 2017; Omotayo, 2015; Osoba \& Tella, 2017). This is coupled with the significant documentation of gender differences in human capital (such as education, age, prior entrepreneurial experience, prior personal experience, and cognitive properties; Chaganti \& Parasuraman, 1996; DeTienne \& Chandler, 2007; Goher, 2013; Kedmeneca, Tominc, \& Rebernik, 2014; Srinivasan, Woo, \& Cooper, 1994; Zavyalova \& Kosheleva, 2010), which may suggest that differences in human capital 
may at least partially explain gender variations in the intentions of business education students to participate in real-life learning tasks.

Traditionally, human capital has been defined in terms of people's productive capabilities and characteristics: In other words, it is seen as knowledge and skills of people (Organization for Economic Co-operation and Development, 2004). It is the knowledge and skills that people acquire through education and training, being a form of capital, as a product of deliberate investment that yields returns (Schultz, 1961). Human capital is described as investing in both formal and informal education and training, which provides and enhances individual's productivity by providing knowledge, skills, and attitudes and motivation that are necessary for economic and social development (Psacharopoulos \& Woodhall, 1985). It is also defined as the acquired human capabilities that are durable traits, which assist in yielding some positive effects upon the performance in socially valued activities (David \& Lopez, 2001).

Human capital has been classified into two major categories: general and specific human capital (Becker, 1964, 1975; Buchholtz, Ribbens, \& Houle, 2003). Becker (1975) described the general human capital as individuals' knowledge and skills that are useful in performing more than one task. This type of human capital is usually measured by items, such as, formal education, age, prior work experiences, and prior entrepreneurial experiences (Gimeno, Folta, Cooper, \& Woo, 1997). As such, providing opportunities for students to participate in real-life learning tasks such as feasibility studies, business planning, simulation exercise, role playing, teaching practice exercise, industrial work experience, field trip, and case study through business education can potentially play an important role in equipping students with divers knowledge and skills to engage in career tasks. Specific human capital on the other hand refers to knowledge and skills that are useful in performing a single task (Becker, 1975). This type of human capital is usually measured by items, such as, prior knowledge and cognitive properties (Venkataraman, 1997; Shane, 2000; Shane \& Venkataraman, 2000). Of course, prior knowledge of creating new products or services, improving new products or services, managing resources, risk-taking, and selling goods can also potentially play an important role in motivating students to engage in entrepreneurial and educational careers upon graduation, thus providing them the access to life-sustaining essentials, such as, food, healthcare, housing and protection, and improve their self-esteem and freedom.

It is based on the above clarifications that Lucas (1988) contended that there are important factors that make human capital productive and these are skills and knowledge. Human capital theory proposes that people with high levels of human capital will definitely reap more desirable outcomes (Becker, 1964). This means that an economy with a larger stock of human capital will experience a fast rate of development. Human capital theory rests on the assumption that formal and informal education and training are necessary to improve the productive capacity of a population. In short, human capital theorists have acknowledged that an educated population is a productive population (Denison, 1962; Mincer, 1962; Psacharopoulos, 1985; Romer, 1990). It emphasizes how education increases the productivity and efficiency of people by increasing their levels of cognitive stock of economically productive human capability, which is a product of innate abilities and investment in human beings. The provision of formal education is viewed as an investment in human capital, which proponents of the theory have considered as equally or even more worthwhile than that of physical capital. In the past, economic strength was largely believed to be hinged on tangible assets such as factory, land, equipment, and machines. Modern economists seem to concur that in the new global economy, education and training are the key to improving the human capital and ultimately increasing the economic development of any nation.

The theoretical framework that helps to explain gender differences in business education students' human capital is social feminism. Because, the theoretical roots of social feminists are derived, at least in part, from social learning theory (Fischer et al., 1993; Johnsen \& McMahon, 2005), which 
postulated that there are differences between males' and females' experiences from the earliest moments of life that result in the fundamentally different ways of viewing the world (Fischer et al., 1993). Social feminism seeks to unravel the ideological nature of human capital as gender divisions (Anthias \& Yuval-Davis, 1983). Essentially, social feminism viewed gender as different but equal, and proposes that the differences between women and men are due to unique socialization processes (Carter \& Williams, 2003; Johnsen \& McMahon, 2005). Social feminist theory suggests that due to the differences in early and ongoing socialization, women and men do differ inherently. It also suggests that this does not mean women are inferior to men, as both may develop different but equally effective traits. The authors of this study suggested that the distinctive experiences among men and women allow them to develop unique human capital, which in turn affects the sustainable development of Nigerian economy. The possession of specific knowledge and skills varies among men and women and these differences strongly influence their intentions to engage in entrepreneurial and lifelong learning tasks. This implies that students use specific knowledge and skills they have acquired to engage in entrepreneurial and lifelong learning tasks.

Based on the differences among male and female business education students' human capital, the author of this research investigated four specific interrelated questions. First, do male and female business education students experience different types of general human capital? Second, do male and female business education students possess different types of general human capital? Third, do the differences in both male and female business education students' general human capital have differential effect on sustainable development of Nigerian economy? And finally, do the differences in both male and female business education students' specific human capital have a differential effect on the sustainable development of Nigerian economy?

The rest of this study is organized as follows. The next sections will be describing the methods used in conducting the study. The data analyses will be presented. The results from data analyses will be discussed. The limitations encountered in the study and suggestions for future research will also be discussed. The implications and recommendations for future practices will be discussed. And finally, logical conclusions will be drawn based on the results of the study.

\section{Methodology}

A cross-sectional survey design, by employing a correlational survey research design was used to achieve the specific objectives of the study. This research investigates the relationship between business education student's human capital and core values of sustainable economic development from a gender perspective. This type of design "involves collecting data to determine whether, and to what degree, a relationship exists between two or more quantifiable variables" (Gay, Mills \& Airasian, 2009, p. 195). Therefore, a correlational design is appropriate for this study in that it would help to determine whether, or the extent to which a relationship exists between two different independent variables (male and female business education students human capital) and one dependent variable (core values of sustainable economic development). The study sample composed of 375 (107 male and 268 female) students of business education in Federal Universities in SouthSouth geopolitical region of Nigeria. This geopolitical region of Nigeria was preferred for the study due to location of author's institution.

The instrument for data collection was a self-constructed questionnaire. The instrument consists of eight items of general human capital, five items of specific human capital, and three items of core values of sustainable economic development, totaling 16 items. A sample of items raised for general human capital is "I have experienced business planning exercise." A sample of items raised for specific human capital is "I possessed prior knowledge of resource management." A sample of items raised for core values of sustainable economic development is "I have acquired the knowledge and skills to become self-reliant." A panel of four lecturers from business education and measurement 
and evaluation ensured the content validity of the instrument. The revised instrument covers types of general human capital, types of specific human capital, and core values of sustainable economic development. The instrument had 4-point scale of 1 (very low extent) to 4 (very high extent), which was administered on 30 students to determine its reliability. The result showed that the instrument was reliable with Cronbach's alpha coefficient of $\alpha=.90$. The bivariate correlation, analysis of variance, and multiple regressions were applied for the data analyses.

\section{Data Analyses}

The results of the data analyzed are presented in Tables 1 to 5 .

Table 1. Mean, Standard Deviation, and Bivariate Correlation of the Study Variables

\begin{tabular}{|c|c|c|c|c|c|c|c|c|c|c|c|c|c|c|c|}
\hline & $M$ & $S D$ & 1 & 2 & 3 & 4 & 5 & 6 & 7 & 8 & 9 & 10 & 11 & 12 & 131 \\
\hline 1. FS & 3.93 & .327 & 1 & & & & & & & & & & & & \\
\hline 2. BPE & 3.73 & .505 & $.446^{* *}$ & 1 & & & & & & & & & & & \\
\hline 3. SE & 3.46 & .578 & $.336^{* *}$ & $.207^{* *}$ & 1 & & & & & & & & & & \\
\hline 4. $\mathrm{RP}$ & 3.35 & .546 & $.298^{* *}$ & $.176^{* *}$ & $.456^{* *}$ & 1 & & & & & & & & & \\
\hline 5. TPE & 3.42 & .578 & $.363^{* *}$ & $.271^{* *}$ & .055 & $.187^{* *}$ & 1 & & & & & & & & \\
\hline 6. IWE & 3.46 & .588 & $.291^{* *}$ & $.254^{* *}$ & .001 & .026 & $.386^{* *}$ & 1 & & & & & & & \\
\hline 7. WV & 3.35 & .536 & $.288^{* *}$ & $.180^{* *}$ & $.119^{*}$ & .060 & $.130^{*}$ & $.332^{* *}$ & 1 & & & & & & \\
\hline 8. $\mathrm{CS}$ & 3.26 & .537 & $.263^{* *}$ & .048 & $.282^{* *}$ & $.190^{* *}$ & .057 & $.265^{* *}$ & $.398^{* *}$ & 1 & & & & & \\
\hline 9. PKNP & 2.65 & .810 & .092 & $.188^{* *}$ & $.212^{* *}$ & $.118^{*}$ & .051 & $-.102^{*}$ & -.053 & -.018 & 1 & & & & \\
\hline 10. PINP & 2.46 & .988 & .074 & $.215^{* *}$ & $.169^{* *}$ & .045 & .024 & $-.110^{*}$ & -.075 & -.094 & $.875^{* *}$ & 1 & & & \\
\hline 11. PKMR & 2.30 & 1.093 & $.116^{*}$ & $.136^{* *}$ & $.290^{* *}$ & $.185^{* *}$ & -.008 & $-.159^{* *}$ & ${ }^{*}-.031$ & .026 & $.814^{* *}$ & $.752^{* *}$ & 1 & & \\
\hline 12. PKRT & 2.21 & 1.141 & .057 & $.108^{*}$ & $.225^{* *}$ & $.167^{* *}$ & .043 & -.095 & -.036 & -.016 & $.770^{* *}$ & $.745^{* *}$ & $.821^{* *}$ & 1 & \\
\hline 13. PKSP & 2.35 & 1.091 & .088 & $.150^{* *}$ & $.145^{* *}$ & $.152^{* *}$ & .078 & -.098 & -.028 & .010 & $.756^{* *}$ & $.703^{* *}$ & $.754^{* *}$ & $.831^{* *}$ & 1 \\
\hline 14. CVSD & 2.26 & .957 & .042 & $.122^{*}$ & $.131^{*}$ & $.116^{*}$ & .073 & -.022 & .033 & .019 & $.711^{* *}$ & $.682^{* *}$ & $.741^{* *}$ & $.779^{* *}$ & $.770^{* *}$ \\
\hline
\end{tabular}

Note. $N=375 . \mathrm{FS}=$ feasibility study; $\mathrm{BPE}=$ business planning exercise; $\mathrm{SE}=$ simulation exercise; $\mathrm{RP}=$ role-playing; $\mathrm{TPE}=$ teaching practice exercise IWE $=$ industrial work experience; $\mathrm{WV}=$ work visit; $\mathrm{CS}=$ case studies; $\mathrm{PKNP}$ = prior knowledge of creating new products; $\mathrm{PINP}$ = prior knowledge of improving new products; PKMR = prior knowledge of managing resources; $\mathrm{PKRT}=$ prior knowledge of risk taking; PKSP = prior knowledge of selling products; CVSD = core values of sustainable development.

The results presented in Table 1 showed that the mean responses of business education students' general human capital range from 3.26 to 3.73 , while the mean responses of their specific human capital range from 2.21 to 2.65 . The aggregate mean responses of business education students' on the core values of sustainable economic development is 2.26 . The table also showed that the correlation coefficient of between variables which ranged from .001 to .814 .

\section{Testing of the Hypotheses}

The data analysis for testing the hypotheses was carried out using analysis of variance and multiple regression statistics.

Hypothesis 1: Male and female business education students experience different types of general human capital. 
Table 2. Summary of Analysis Of Variance on General Human Capital Based on Gender

\begin{tabular}{|c|c|c|c|c|c|c|c|c|c|}
\hline & \multicolumn{5}{|c|}{ General Human Capital } & \multirow[b]{3}{*}{$F$} & \multirow[b]{3}{*}{$p$} & \multirow[b]{3}{*}{ Decision } \\
\hline & & \multicolumn{2}{|c|}{$\begin{array}{c}\text { Male } \\
(n=107)\end{array}$} & \multicolumn{2}{|c|}{$\begin{array}{l}\text { Female } \\
(n=268)\end{array}$} & \multirow[b]{2}{*}{ SS/MS } & & & \\
\hline & & $M$ & $S D$ & $M$ & $S D$ & & & & \\
\hline 1 & Feasibility studies & 3.83 & .485 & 3.96 & .226 & 1.311 & 12.664 & .000 & Sig. \\
\hline 2 & $\begin{array}{l}\text { Business planning } \\
\text { exercise }\end{array}$ & 3.64 & .589 & 3.77 & .463 & 1.433 & 5.691 & .018 & Sig. \\
\hline 3 & $\begin{array}{l}\text { Simulation } \\
\text { exercise }\end{array}$ & 3.31 & .692 & 3.51 & .515 & 3.261 & 9.990 & .002 & Sig. \\
\hline 4 & Role-playing & 3.25 & .631 & 3.39 & .504 & 1.487 & 5.041 & .025 & Sig. \\
\hline 5 & $\begin{array}{l}\text { Teaching practice } \\
\text { exercise }\end{array}$ & 3.35 & .715 & 3.44 & .513 & .738 & 2.213 & .138 & $n s$ \\
\hline 6 & $\begin{array}{l}\text { Industrial work } \\
\text { experience }\end{array}$ & 3.35 & .578 & 3.51 & .508 & 1.999 & 5.861 & .016 & Sig. \\
\hline 7 & Work visit & 3.32 & .653 & 3.37 & .483 & .176 & .610 & .435 & $n s$ \\
\hline 8 & Case study & 3.17 & .680 & 3.29 & .465 & 1.225 & 4.282 & .032 & Sig. \\
\hline
\end{tabular}

Note. $d f=373 . \mathrm{SS}=$ sum of squares; MS = mean of squares; Sig. = significant; $n s=$ not significant.

The results presented in Table 2 showed that the male and female students of business education statistically differ in their experience of 6 types of general human capital $(F=4.286-12.664 ; p=$ $.000-.032$ ), while two types of general human capital are not statistically significant. Thus, Hypothesis 1 is partly supported in this study.

Hypothesis 2: Male and female business education students possess different types of specific human capital.

Table 3. Summary of Analysis of Variance on Specific Human Capital Based on Gender

\begin{tabular}{|c|c|c|c|c|c|c|c|c|c|}
\hline & \multicolumn{5}{|c|}{ Specific Human Capital } & \multirow[b]{3}{*}{$F$} & \multirow[b]{3}{*}{$p$} & \multirow[b]{3}{*}{ Decision } \\
\hline & & \multicolumn{2}{|c|}{$\begin{array}{c}\text { Male } \\
(n=107)\end{array}$} & \multicolumn{2}{|c|}{$\begin{array}{l}\text { Female } \\
(n=268)\end{array}$} & \multirow[b]{2}{*}{ SS/MS } & & & \\
\hline & & $M$ & $S D$ & $M$ & $S D$ & & & & \\
\hline 9 & $\begin{array}{l}\text { Prior knowledge of } \\
\text { Creating new } \\
\text { products }\end{array}$ & 3.26 & .691 & 2.40 & .720 & 56.385 & 111.191 & .000 & Sig. \\
\hline 10 & $\begin{array}{l}\text { Prior knowledge of } \\
\text { Improving new } \\
\text { products }\end{array}$ & 3.18 & .711 & 2.18 & .938 & 76.806 & 99.342 & .000 & Sig. \\
\hline 11 & $\begin{array}{l}\text { Prior knowledge of } \\
\text { Managing } \\
\text { resources }\end{array}$ & 3.18 & .822 & 1.95 & .988 & 114.954 & 129.152 & .000 & Sig. \\
\hline 12 & $\begin{array}{l}\text { Prior knowledge of } \\
\text { Risk-taking }\end{array}$ & 3.09 & .864 & 1.86 & 1.046 & 115.976 & 116.615 & .000 & Sig. \\
\hline 13 & $\begin{array}{l}\text { Prior knowledge of } \\
\text { Selling products }\end{array}$ & 3.19 & .881 & 2.01 & .983 & 105.035 & 115.162 & .000 & Sig. \\
\hline
\end{tabular}

Note. $d f=373$. SS = sum of squares; MS = mean of squares; Sig. = significant.

The results presented in Table 3 showed that the male and female students of business education significantly differ in the five types of specific human capital $(F=99.342-129.152 ; p=.000)$. The table also depicts that male students possess specific human capital than the female students. Thus, Hypothesis 2 is supported.

Hypothesis 3: Differences in both male and female business education students' general human capital have a significant impact on core values of sustainable economic development. 
Table 4. Multiple Regression of General Human Capital on Core Values of Sustainable Economic Development

\begin{tabular}{|c|c|c|c|c|c|c|c|c|c|c|}
\hline & \multicolumn{10}{|c|}{ General Human Capital } \\
\hline & \multicolumn{5}{|c|}{ Malea $^{a}$} & \multicolumn{5}{|c|}{ Femaleb $^{b}$} \\
\hline & $B$ & $S E$ & $\beta$ & $T$ & Sig. & $B$ & $S E$ & $\beta$ & $T$ & Sig. \\
\hline$\overline{\text { (Constant) }}$ & .615 & .451 & & & & .400 & 1.035 & & .386 & .700 \\
\hline 1. FS & .049 & .157 & .033 & .312 & .756 & -.169 & .204 & -.050 & -.828 & .408 \\
\hline 2. BPE & -.096 & .140 & -.078 & -.689 & .493 & .348 & .101 & .211 & 3.461 & .001 \\
\hline 3. SE & .024 & .108 & .023 & .224 & .823 & .401 & .097 & .272 & 4.150 & .000 \\
\hline 4. $\mathrm{RP}$ & -.144 & .117 & -.124 & -1.227 & .223 & .199 & .092 & .132 & 2.157 & .032 \\
\hline 5. TPE & .284 & .113 & .278 & 2.507 & .014 & .035 & .091 & .024 & .389 & .698 \\
\hline 6. IWE & .195 & .110 & .198 & 1.776 & .079 & -.131 & .091 & -.087 & -1.435 & .152 \\
\hline 7. WV & .129 & .122 & .115 & 1.053 & .295 & -.073 & .093 & -.046 & -.789 & .431 \\
\hline 8. CS & .347 & .110 & .324 & 3.169 & .002 & -.200 & .102 & -.122 & -1.964 & .051 \\
\hline
\end{tabular}

Note. $\mathrm{FS}=$ feasibility study; $\mathrm{BPE}=$ business planning exercise; $\mathrm{SE}=$ simulation exercise; $\mathrm{RP}=$ roleplaying; $\mathrm{TPE}=$ teaching practice exercise; $\mathrm{IWE}=$ industrial work experience; $\mathrm{WV}=$ work visit; $\mathrm{CS}=$ case studies.

${ }^{\mathrm{a}} R^{2}=.455$; adjusted $R^{2}=.410 ; F(8,98)=10.207(p=.000) .{ }^{\mathrm{b}} R^{2}=.195 ;$ adjusted $R^{2}=.170 ; F(8,259)=$ $7.852(p=.000)$.

The results presented in Table 4 showed that both male and female students of business education statistically significant in the overall model; Male $[\mathrm{F}(8,98)=10.207, \mathrm{P}<.001]$, Female $[\mathrm{F}(8,259)=$ $7.852, \mathrm{P}<.001]$. The adjusted $\mathrm{R}^{2}$ revealed that $45.5 \%$ and $19.5 \%$ for male and female respectively, which indicates that changes or variances in core values of sustainable economic development cause by general human capital is higher in Male than Female students. However, the Table showed that Male students significantly differ in one type of general human capital than Female, while Female students significantly differ in four types of general human capital than the Male students.

Hypothesis 4: differences in both male and female business education students' specific human capital have a significant impact on core values of sustainable economic development.

Table 5. Multiple Regression of Specific Human Capital on Core Values of Sustainable Economic Development

\begin{tabular}{lcccccccccc}
\hline & \multicolumn{10}{c}{ Male $^{\mathbf{a}}$} \\
\cline { 2 - 12 } & $\boldsymbol{B}$ & $\boldsymbol{S E}$ & $\boldsymbol{\beta}$ & $\boldsymbol{T}$ & Sig. & $\boldsymbol{B}$ & $\boldsymbol{S E}$ & $\boldsymbol{\beta}$ & $\boldsymbol{T}$ & Sig. \\
\hline (Constant) & .325 & .216 & & 1.506 & .133 & .840 & .128 & & 6.559 & .000 \\
9. PKNP & .185 & .092 & .175 & 2.012 & .047 & -.150 & .121 & -.142 & -1.242 & .215 \\
10. PINP & .208 & .095 & .203 & 2.194 & .031 & .084 & .075 & .103 & 1.122 & .263 \\
11. PKMR & .128 & .089 & .145 & 1.444 & .152 & .124 & .061 & .161 & 2.016 & .045 \\
12. PKRT & .171 & .088 & .203 & 1.941 & .055 & .263 & .060 & .361 & 4.397 & .000 \\
13. PKSP & .210 & .078 & .254 & 2.701 & .008 & .245 & .055 & .316 & 4.434 & .000 \\
\hline
\end{tabular}

Note. PKNP = prior knowledge of creating new products; PINP = prior knowledge of improving new products; $\mathrm{PKMR}=$ prior knowledge of managing resources; $\mathrm{PKRT}=$ prior knowledge of risk taking; PKSP $=$ prior knowledge of selling products.

${ }^{a} R^{2}=.670 ;$ adjusted $R^{2}=.653 ; F(5,101)=40.967(p=.000)$. ${ }^{\mathrm{b}} R^{2}=.538 ;$ adjusted $R^{2}=.530 ; F(5,262)$ $=61.101(p=.000)$. 
The results presented in Table 5 showed that male students of business education, $F(5,101)=$ 40.967, $p<.001$, and female business education students, $F(5,262)=61.101 ; p<.001$, showed statistical significant on relationship between the possessed specific human capital and core values of sustainable economic development. The adjusted $R^{2}$ of male students $(65.3 \%)$ is higher than that of female students (53.8\%), respectively, indicating that changes or variances that would occur in core values of sustainable economic development, caused by specific human capital is higher in male than female students. However, male students showed statistical significant differences in four types of specific human capital, while female students also showed alternate statistical significant differ in four types of specific human capital.

\section{Discussion}

The specific aim of this study is to determine the relationship between business education and sustainable development of Nigerian economy from a gendered perspective. The research study has contributed not only to the study of sustainable development of economies, but it also provides the support for the assumptions of social feminist and human capital theories. Using the descriptive statistics of mean, standard deviations and bivariate correlation, the study found a positive relationship between higher levels of both general and specific human capital and core values sustainable economic development. These results conform to the bulk of research findings which established a positive correlation between human capital and sustainable development of Nigerian economy (Eigbiremolen \& Anaduaka, 2014; Ekperiware et al., 2017; Idenyi et al., 2016; Ogujiuba, 2013; Omotayo, 2015; Osoba \& Tella, 2017).

The study was also designed to test four hypotheses. Hypothesis 1 was formulated to test if male and female students of business education experience different types of general human capital. Hypothesis 2 was formulated to test if male and female students of business education possess different types of general human capital. Hypothesis 3 was also formulated to test if differences in male and female business education students' general human capital would have a significant effect on sustainable economic development. Finally, Hypothesis 4 was further formulated to test if differences in male and female business education students' specific human capital would have a significant effect on sustainable economic development.

Hypothesis 1 partly supports the result of the study, as male and female business education students experience almost the same types of general human capital. Thus, the pool of research evidence to support this finding is limited, nevertheless, it concurred with the general assumption of social feminism that "women and men have different experiential backgrounds and different ways of thinking" (Carter \& Williams, 2003, p. 30). In addition, the result from Hypothesis 1 that male and female students experience almost the same types of general human capital supports another assumption of social feminism which suggests that women and men experience different types of general human capital, but neither the male mode of learning experiences is inherently superior to the female mode of exposure to learning experiences (Fischer et al., 1993). However, the unique stocks of general human capital that male and female students of business education have been experiencing differentially may influence their interest to participate in formal and informal learning activities.

Hypothesis 2 supported the results of the study, as male students of business education possess higher level of specific human capital than female students of business education. This result conforms to the general tenets of liberal feminism, which is often contrasted with social feminism that women have been denied critical resources (for example, role models, social networks) to acquire higher levels of specific human capital (such as, creativity, innovation, problem solving). The elimination of these discriminatory practices will result in equal opportunities for female business education students (Carter \& Williams, 2003) to contribute to sustainable development of Nigeria. 
This finding has called for the implementation of new policies in business education program to increase the number of female professors who will serve as role models to female students of business education.

Hypothesis 3 supported the results of the study, as changes or variance in core values of sustainable development caused by general human capital is higher in male than female students of business education. Again, this result concurs to general assumption of social feminism that women and men have different experiential backgrounds and different ways of thinking (Carter \& Williams, 2003). It also agrees with proposition of social feminism that differences between women and men are due to unique career socialization processes (Carter \& Williams, 2003; Johnsen \& McMahon, 2005).

According to Becker (1964), people (including business education students) with higher experiential level of general human capital through formal and informal education will definitely reap more desirable outcomes (Becker, 1964). Thus, the result of this study that male students of business education experience higher levels of general human capital than their female counterparts, suggests that male students of business education would contribute significantly to sustainable development because they utilize their unique knowledge and skills they have to engage in entrepreneurial and lifelong learning tasks.

Hypothesis 4 supported the results of the study, as changes or variances that would occur in core values of sustainable development caused by the specific human capital is higher in male students of business education than their female counterpart. Becker (1991) earlier argued that women's important role in reproduction reduces their professional career productivity and human capital investment. This is apparently the reason why Carter and Silva (2010) found in their research that women continue to lag men at every single career stage, right from their first professional careers. The possession of specific human capital that varies among both men and women has suggested that male students of business education have higher chance to engage in entrepreneurial and educational careers upon graduation. Because business education students utilized specific skills and knowledge they have acquired to promote quality standard of living, self-esteem, and freedom from social servitude.

\section{Limitations of the Study and Suggestions for Future Research}

As often said, there is no research without limitation. Therefore, this extant research has some obvious limitations. However, the research has provided empirical evidence regarding the relationship between business education and sustainable development of Nigerian economy from a gendered perspective. First, because the data were collected through a nonexperimental means (i.e., a cross-sectional survey or by employing a correlational survey research design), causal inference could not be made in the study. The author, therefore, recommend that longitudinal and experimental study be conducted so as to improve and provide better results. Second, because the sample size of participants was drawn from a single (federal) university setting in South-South geopolitical zone of Nigeria, caution should be exercise in generalizing results. Therefore, future research should aim at determining the inclusion of more proportionally representative samples (for example, South-East, South-West, North-East, North-West, and North-Central) to allow a more equal and balanced results from all federal universities in Nigeria. Third, because the research participants are homogenous, which were business education students only, caution should also be exercise in generalizing results to students in other fields of study. As such, these categories of students were use in the study because they are currently offering a course designed to equip them with the knowledge and skills needed to engage in entrepreneurial and educational careers right after graduation. Therefore, there is the need for further studies that include other categories of students (or participants) from other vocationally oriented educational disciplines. 


\section{Implications and Recommendations for Future Practice}

There is an obvious variation among male and female business education students' human capital, and these differences tend to strongly influence their intentions or decisions to participate in sustainable development agenda, both in Nigeria and other parts of the world. The results of this study, therefore, have implications for educational stakeholders and researchers concerning the role of gender on sustainable development. The research found a positive correlation between specific and general human capital and core values of sustainable development. It would thus be very needful for stakeholders to collaboratively invest their resources on business education in so as to ensure implementation of typical instructional methods that would increase student's access to hands-on experience. The study also found that male students possess higher levels of specific human capital than their female counterpart. It would thus be very needful for all stakeholders to collaboratively address the gender variations among business education student's specific human capital by providing them equal opportunities to participate in real-life learning activities so as to expose them to prior knowledge of entrepreneurial experience. The research further found that the variances that occur in core values of sustainable development caused by both general and specific human capital are higher in male students than the female students. It would thus be very needful for all major stakeholders to collaboratively provide the resources that would be directed toward apprenticeship programs to equally equip male and female business education student's with knowledge and skills to participate in sustainable development agenda of Nigeria.

\section{Conclusion}

From the findings of this study, it appears based on the overall model that there is a positive link between human capital and core values of sustainable economic development. The research founded a significant difference in the accumulation of specific human capital among male and female business education students. The research further founded variance in the core values of sustainable development, and which were caused by the accumulation of both general and specific human capital in male business education students than their female counterparts. It is therefore concluded that the implementation of typical instructional methods would help in increasing student's access to hands-on experiences. The provision of equal opportunities to both male and female students of business education to participate in real-life activities would help in exposing them to prior knowledge of entrepreneurial experience. In addition, directing business education toward apprenticeship programs would equally equip male and female students with the knowledge and skills to participate in sustainable economic development agenda of Nigeria.

\section{References}

Adelakun, O. J. (2011). Human capital development and economic growth in Nigeria. European Journal of Business and Management, 3, 29-38. Retrieved from https://www.iiste.org/Journals/index.php/EJBM/article/download/645/538

Ali, M., Egbetokun, A., \& Memon, M. H. (2017). Human capital, social capabilities and economic growth. Economies, 6, 1-18. Retrieved from www.mdpi.com/2227-7099/6/1/2/pdf

Ametefe, G. T. D., \& Ametefe, M. D. (2007). Re-positioning women education for national development in the 21st century. Journal of Research Development, 8, 68-72. Retrieved from http://globalacademicgroup.com/journals/nard/Gilbert.pdf

Anthias, F., \& Yuval-Davis, N. (1983). Contextualizing feminism: Gender, ethnic and class divisions. Feminist Review, 15, 62-75.

Ball, J. A. (2012). The gender in undergraduate business programmes in the United States. Journal of Education, 87, 260-265. doi: 10.1080/08832323.2011.617792 
Becker, G. (1964). Human capital: A theoretical and empirical analysis with special reference to education. Chicago, IL: University of Chicago Press.

Becker, G. (1975). Human capital. New York, NY: Columbia University Press.

Becker, G. S. (1991). A treatise on the family. Cambridge, MA: Harvard University Press.

Becker, G. S. (1993). Human capital: A theoretical and empirical analysis with specific reference to education. Chicago, IL: University of Chicago Press.

Blau, G., Mittal, N., Schirmer, M., \& Ozkan, B. (2017). Differences in business undergraduate perceptions by preferred classroom learning environment. Journal of Education for Business, 92, 280-287. doi: 10.1080/08832323.2017.1365679

Buchholtz, A. K., Ribbens, B. A., \& Houle, I. T. (2003). The role of human capital in post-acquisition CEO departure. Academy of Management Journal, 46, 506-514.

Carter, N. M., \& Silva, C. (2010). Women in management: Delusions of progress. Harvard Business Review, 88, 19-21.

Carter, N. M., \& Williams, M. L. (2003). Comparing social feminism and liberal feminism: The case of new firm growth. In J. E. Butler (Ed.), New perspectives on women entrepreneurs (pp. 2550). Greenwich, CT: Information Age Publishing.

Chaganti, R., \& Parasuraman, S. (1996). A study of the impacts of gender on business performance and management patterns in small businesses. Entrepreneurship Theory and Practice, 21, $73-75$.

David, P., \& Lopez, J. (2001). Knowledge, capabilities and human capital formation in economic growth (Treasury Working Paper 01/13). Retrieved from www.treasury.govt.nzworking papers/2001/twp01-13.pdf

Denison, E. F. (1962). The sources of economic growth in the United States and the alternatives before us. New York, NY: Committee for Economic Development.

DeTienne, D. R., \& Chandler, G. N. (2007). The role of gender in opportunity identification. Entrepreneurship Theory and Practice, 20, 365-386.

Eigbiremolen, G. O., \& Anaduaka, U. S. (2014). Human capital development and economic growth: The Nigeria experience. International Journal of Academic Research in Business and Social Sciences, 4, 25-35.

Ekpenyong, L. E., \& Edokpolor, E. J. (2015). Winning the war against unemployment and poverty in Nigeria: Is there a role for TVET-private sector partnership? The Nigerian Vocational Association Journal, 20, 125-132.

Ekperiware, M. C., Olatayo, T. O., \& Egbetokun, A. (2017). Human capital and sustainable development in Nigeria: How can economic growth suffice environmental degradation? (Economics Discussion Papers, No. 2017-29). Kiel, Germany: Kiel Institute for the World Economy.

Federal Republic of Nigeria (FRN). (2017). Nigeria sustainable development goals (SDGs) indicators baseline report 2016. Retrieved from

http://www.ng.undp.org/content/dam/nigeria/docs/SDGs/Nigeria\%20SDGs\%20Indicators\%20 Baseline\%20Report\%202016.pdf

Fischer, E. M., Reuber, A. R., \& Dyke, L. S. (1993). A theoretical overview and extension of research on sex, gender, and entrepreneurship. Journal of Business Venturing, 8, 151-168.

Gay, L. R., Mills, G. E., \& Airasian, P. (2009). Educational research: Competencies for analysis and applications (9th ed.). Upper Saddle River, NJ: Merrill. 
Gimeno, J., Folta, T., Cooper, A., \& Woo, C. (1997). Survival of the fittest: Entrepreneurial human capital and the persistence of underperforming firms. Administrative Science Quarterly, 42, 750-783.

Goher, F. (2013) Gender inequality in human capital accumulation and economic growth: A comparative analysis of Pakistan and Sri Lanka. Asia Pacific Journal of Social Work and Development, 23, 242-252. doi: 10.1080/02185385.2013.778786

Hardi, P. A. (1997). Assessing sustainable development: Principles in practice. Manitoba, Canada: International Institute for Sustainable Development. Retrieved from https://www.iisd.org/pdf/bellagio.pdf

Idenyi, O. S., Eze, O. R., \& Ogbonna, O. S. (2016). Analysis of the relationship between human capital development and economic growth in Nigeria. European Journal of Accounting, Auditing and Finance Research, 4, 56-71.

Igbinedion, V. I., \& Ojeaga, I. J. (2013). Redressing gender inequality in Nigerian educational system through office technology and management programme. Benin Journal of Gender Studies, 3, $112-125$.

Johnsen, G. J., \& McMahon, R. (2005). Owner-manager gender, financial performance and business growth amongst SMEs from Australia's business longitudinal survey. International Small Business Journal, 23, 115-142.

Kaenzig, R. Hyatt, E. \& Anderson, S. (2007). Gender differences in college of business educational experiences. Journal of Education for Business, 83, 95-100.

Kedmenec, I., Tominc, P., \& Rebernik, M. (2014). Gender differences in the usage of resources in the entrepreneurial opportunity identification process in Slovenia and Croatia. Economic Research-Ekonomska Istraživanja, 27, 366-377.

Kelan, E. K., \& Jones, R. D. (2010). Gender and the MBA. Academy of Management Learning and Education, 9, 26-43.

Kuépié, M. (2016). Determinants of labour market gender inequalities in Cameroon, Senegal and Mali: The role of human capital and fertility burden. Canadian Journal of Development Studies, 37, 66-82. doi: 10.1080/02255189.2016.1122580

Kurya, U. L., \& Hassan, B. (2007). Technical and vocational education for productive and sustainable development in Nigeria. Proceedings of the 20th Annual Conference of the Nigeria Association of Teachers of Technology (NATT), Kaduna, Nigeria.

Lucas, R. (1988). On the mechanics of economic development. Journal of Monetary Economics, 22, 342.

Mba, I. C., Mba, E. I., Ogbuabor, J. E., \& Ikpegbu, C. H. (2013). Human capital development and economic growth in Nigeria. Journal of Economics and Sustainable Development, 4, 48-52.

Miller, G. L., \& Sisk, F. A. (2012). Business education and gender bias at the "C-level." Administrative Issues Journal: Education, Practice and Research, 2, 16-25. Retrieved from https://www.swosu.edu/academics/aij/2012/v2i1/Volume2-Issue1.pdf

Mincer, J. (1962). On-the-job training: Costs, returns and some implications. Journal of Political Economy, 70, 50-79.

Morley, L. (2013). Women and higher education leadership: Absences and aspirations. London, United Kingdom: Leadership Foundation for Higher Education.

Nordman, C., \& Wolff, F. C. (2009). Is there a glass ceiling in Morocco? Evidence from matched worker-firm data. Journal of African Economies, 18, 592-633. 
Ogujiuba, K. (2013). The impact of human capital formation on economic growth in Nigeria. Journal of Economics, 4, 121-132.

Ogunleye, O. O., Owolabi, O. A., Sanyaolu, O. A., \& Lawal, O. O. (2017). Human capital development and economic growth in Nigeria. IJRDO Journal of Business Management, 3, 17-37.

Omotayo, O. A. (2015). Impact of human capital development on economic growth in Nigeria. International Journal of Recent Research in Commerce Economics and Management, 2, 151164.

Organization for Economic Co-Operation and Development. (2004). Career guidance and public policy: Bridging the gap. Paris, France: Author.

Osoba, A. M., \& Tella, S. A. (2017). Human capital variables and economic growth in Nigeria: An interactive effect. EuroEconomica, 36, 1. Retrieved from http://journals.univdanubius.ro/index.php/euroeconomica/article/view/3332/4054

Psacharopoulos, G. (1985). Returns to education: A further international update and implications. Journal of Human Resources, 20, 583-601.

Psacharopoulos, G., \& Woodhall, M. (1985). Education for development: An analysis of investment choices. Oxford, United Kingdom: Oxford University Press. Retrieved from http://documents.worldbank.org/curated/en/477701468137718173/pdf/multi-page.pdf

Riley, G. A. (1987). Gender bias of the case method in business education. Journal of Education for Business, 64, 149-152.

Romer, P. M. (1990). Endogenous technological change. Journal of Political Economy, 98, 71-102.

Sammons, P. (1995). Gender, ethnic and socio-economic differences in attainment and progress: A longitudinal analysis of student achievement over 9 years. British Educational Research Journal, 21, 465-485.

Schultz, T. W. (1961) Education and economic growth. In N. B. Henry (Ed.). Social forces influencing American education. Chicago, IL: University of Chicago Press.

Sen, A. (1999). Development as freedom. Oxford, United Kingdom: Oxford University Press.

Shane, S. (2000). Prior knowledge and the discovery of entrepreneurial opportunities. Organization Science, 11, 448-469.

Shane, S., \& Venkataraman, S. (2000). The promise of entrepreneurship as a field of research. Academy of Management Review, 25, 217-226.

Simpson, R. (2006). Masculinity and management education: Feminizing the MBA. Academy of Management Learning \& Education, 5, 182-193.

Siphambe, H. K., \& Thokweng-Bakwena, M. (2001). The wage gap between men and women in Botswana's formal labour market. Journal of African Economies, 10, 127-142.

Srinivasan, R., Woo, C., \& Cooper, A. (1994). Performance determinants for male and female entrepreneurs. In W. D. Bygrave, S. Birley, N. C. Churchill, E. Gatewood, F. Hoy, R. H. Keeley, \& W. E. Wetzel Jr. (Eds.), Frontiers of entrepreneurship research (pp. 43-56). Wellesley, MA: Babson Center for Entrepreneurial Studies.

Titiloye, K. A., \& Muhammed, A. A. (2016). Ethical issues in the usage of new technologies among students of business education in tertiary institutions. Nigerian Journal of Business Education, 3, 61-70.

Todaro, M. P., \& Smith S. C. (2011). Economic development. Harlow, England: Pearson Education Inc. 
United Nations Educational Scientific and Cultural Organization. (2005). Contributing to a more sustainable future: Quality education, life skills, and education for sustainable development. Retrieved from http://unesdoc.unesco.org/images/0014/001410/141019e.pdf

Venkataraman, S. (1997). The distinctive domain of entrepreneurship research: An editor's perspective. Advances in Entrepreneurship, Firm Emergence, and Growth, 3, 119-138.

World Commission on Environment and Development. (1987). Our common future: Report of the 1987 World Commission on Environment and Development. Oslo, Norway: United Nations.

World Environmental Education Congress. (2015). Summary report. Presented at the 8th World Environmental Education Congress, Gothenburg Sweden. Retrieved from http://weec2015.org/wp-content/uploads/2015/08/WEEC2015-Summary-Report.pdf.

Zavyalova, E. K., \& Kosheleva, S. V. (2010). Gender stereotyping and its impact on human capital development in contemporary Russia. Human Resource Development International, 13, 341349. doi: 10.1080/13678868.2010.483823

The Journal of Educational Research and Practice provides a forum for studies and dialogue that allows readers to better develop social change in the field of education and learning. Journal content may focus on educational issues of all ages and in all settings. It also presents peer-reviewed commentaries, book reviews, interviews of prominent individuals, and additional content. The objectives: We publish research and related content that examines current relevant educational issues and processes aimed at presenting readers with knowledge and showing how that knowledge can be used to impact social change in educational or learning environments. Additional content provides an opportunity for scholarly and professional dialogue regarding that content's usefulness in expanding the body of scholarly knowledge and increasing readers' effectiveness as educators. The journal also focuses on facilitating the activities of both researcher-practitioners and practitioner-researchers, providing optimal opportunities for interdisciplinary and collaborative thought through blogging and other communications.

Walden University Publishing: http://www.publishing.waldenu.edu 